\title{
Kredietcrisis en de interne beheersing bij verzekeraars
}

\section{Felix Smeulders, Jack Hillenga en Samantha Krishan}

SAMENVATTING In dit artikel wordt ingegaan op de interne beheersing bij verzekeraars. De aanleiding voor dit artikel is de kredietcrisis en de daaruit voortvloeiende extra aandacht voor de interne beheersing bij verzekeraars. Om een beeld te krijgen van de mogelijke ontwikkelpunten voor de interne beheersing bij verzekeraars is aan de hand van de 'levers of control' van Simons de interne beheersing bij 's werelds grootste verzekeraar, AIG, geanalyseerd. Deze analyse heeft inzicht gegeven in welke belangrijke elementen van interne beheersing wel en niet geïmplementeerd zijn bij AIG volgens het model van Simons. Vervolgens wordt een aantal mogelijkheden uiteengezet om de interne beheersing bij verzekeraars verder te ontwikkelen. Hierbij is uitgegaan van de bedrijsactiviteiten die verzekeraars ontplooien en de daarbij horende doelstellingen en ambities ten aanzien van interne beheersing.

\section{RELEVANTIE VOOR DE PRAKTIJK Interne beheersing is bij verzekeraars al jaren een belangrijk punt op de managementagenda. De lessen die getrokken kunnen worden uit de gevolgen van de kredietcrisis helpen in het verder optimaliseren van de interne beheersing bij verzekeraars.}

zijn niet meer te overzien. De centrale banken moeten ingrijpen en regeringen moeten ingrijpende maatregelen treffen met de hoop een einde te maken aan de reeks dagelijkse negatieve verrassingen, zodat de rust op de financiële markten kan wederkeren en de schade voor de reële economie beperkt blijft. Het ziet er namelijk naar uit dat de kredietcrisis de reële economie zo sterk negatief beïnvloedt dat de zwaarste recessie sinds de jaren '30 van de twintigste eeuw voor de deur staat (Battles en Groot, 2008). $\mathrm{Na}$ het omvallen van Lehman Brothers en Washington Mutual, de overname van Merrill Lynch en de redding van AIG, Dexia en Fortis is het de vraag hoe het zover heeft kunnen komen. De hele wereld is op dit moment op zoek naar een antwoord op de vraag: had de kredietcrisis voorkomen kunnen worden en wat zou daar dan de rol van de betrokken partijen in geweest zijn?

In dit artikel willen wij ons beperken tot de rol van verzekeraars in het financiële systeem en de manier waarop zij hun interne beheersing moeten vormgeven. Interne beheersing is voor verzekeraars altijd een belangrijk agendapunt geweest. Door de huidige kredietcrisis komt er alleen maar extra aandacht voor de mate van interne beheersing bij verzekeraars. Het aloude dilemma van business kunnen genereren en de juiste mate van control staan altijd op gespannen voet met elkaar.

Wij gaan niet in op de beantwoording van de vraag of de verzekeraars het anders hadden moeten doen de afgelopen jaren, maar op de vraag: wanneer heeft een verzekeraar voldoende mate van interne beheersing om ook zeer turbulente tijden van een kredietcrisis beter te doorstaan? De beantwoording van deze vraag is gebaseerd op literatuurstudie en een casestudie van het verzekeringsbedrijf AIG.

Er is een einde gekomen aan jaren van economische voorspoed. Er wordt gevreesd voor een recessie in de Verenigde Staten en de Europese Centrale Bank (ECB) heeft voor 2009 de groeiverwachtingen voor de Eurozone verlaagd. Ook Nederland ondervindt de gevolgen van de kredietcrisis. De omvang, kosten en gevolgen van de kredietcrisis
Het artikel is als volgt opgebouwd. In paragraaf 2 wordt ingegaan op de gevolgen van de kredietcrisis voor verzekeraars. In paragraaf 3 wordt ingegaan op de rol van verzekeraars in het financiële systeem. In paragraaf 4 wordt ingegaan op de 
'levers of control' van Simons als inleiding op de analyse van de interne beheersing binnen verzekeraars. In paragraaf 5 wordt met een casestudy dit instrument verder uitgediept. De basis voor deze analyse betreffen de voor de interne beheersing relevante wet- en regelgeving en nieuwsartikelen. In paragraaf 6 komen wij op basis van de in paragraaf 5 beschreven analyse tot zes aanbevelingen die de effectiviteit van de interne beheersing bij verzekeraars kunnen vergroten. Er wordt afgesloten met een korte conclusie.

\section{Wat zijn de gevolgen van de kredietcrisis voor verzekeraars?}

Volgens het officiële antwoord op de website van het Verbond van Verzekeraars ${ }^{2}$ heeft de kredietcrisis maar beperkte impact op de verzekeringssector in Nederland. Verzekeraars hebben niet de unieke liquiditeitsproblematiek van banken: de "bank run". Voor levenproducten gaan verzekeraars langjarige contracten aan met zekerheid van premie-inkomsten. Bij schadeproducten kunnen klanten wel snel overstappen, maar dan valt ook het risico weg.

Volgens het Verbond van Verzekeraars is de impact beperkt. Naar onze mening is er echter wel een aantal zaken aan te duiden die het gevolg zijn van de kredietcrisis en die de verzekeraars voor een uitdaging stellen.

\section{Risicomanagement}

De kredietcrisis heeft ertoe geleid dat verzekeraars kritisch zijn gaan kijken naar hun risicomanagementframework. Het is bijvoorbeeld gebleken dat maar een aantal verzekeraars begreep wat de impact was van de accumulatie van aandelenrisico aan de productzijde. De snelle neergang van de aandelenkoersen, gecombineerd met accountingfraude heeft de financiële veerkracht van veel verzekeraars op de proef gesteld. Daarnaast was een aantal verzekeraars bijvoorbeeld niet in staat vrij snel te bepalen wat de positie was die zij hadden op het moment dat Lehman Brothers failliet ging. Veel verzekeraars zijn op dit moment dan ook aan het bepalen hoe zij hun risicomanagement moeten aanpassen dan wel aanscherpen.

\section{Klantvraag}

Door de kredietcrisis vragen klanten steeds meer om garanties en vertrouwen. Dit heeft een tegenbeweging tot gevolg: waar de verzekeraars de afgelopen decennia steeds meer hebben geprobeerd het risico van producten bij de klant te leggen wordt het risico nu steeds meer bij de verzekeraar teruggelegd. Als gevolg hiervan wordt de kapitaalseis voor de verzekeraar weer hoger.

Deze verandering van de markt, klantvraag, zorgt dat verzekeraars terug willen keren naar hun kerntaak van risico dragen en spreiden en veel minder de behoefte hebben deel te nemen aan het handelen in risico's. Dit zal op haar beurt ook weer leiden tot een versimpeling van het productenpalet van verzekeraars.

\section{Liquiditeit}

In deze tijd is naast oog voor solvabiliteit extra aandacht vereist voor liquiditeitsmanagement. Verzekeraars moeten er alles aan doen om ervoor te zorgen dat ze niet gedwongen worden assets te verkopen. Op dat moment worden de ongerealiseerde verliezen realiteit. Onderdeel van dit liquiditeitsmanagement moet zijn het gebruik maken van scenarioplanningen.

De vraag naar liquiditeit als gevolg van de kredietcrisis brengt voor verzekeraars een aantal uitdagingen met zich mee. De volatiele, illiquide en gesloten kapitaalmarkt heeft tot gevolg dat de kosten van kapitaal oplopen en dat er een beperkte beschikbaarheid is van kapitaal. Dit terwijl de regelgevers, nog meer dan in normale omstandigheden, hun focus leggen op de kapitaalbuffer van verzekeraars. De regelgevers nemen daarin dan ook een steeds conservatiever standpunt over in met als gevolg een verhoging van de kapitaaleis.

\section{Solvency II en economic capital}

In de aanloop op de implementatie van het nieuwe EU-regime van verzekeraars Solvency II waren veel verzekeraars gestart met het aansterken van hun Enterprise Risk Managementdiscipline. Voor Solvency II staan twee onderdelen centraal: - Marktwaarde balans: De gehele balans, zowel activa als de verplichtingen, moet tegen marktwaarde gewaardeerd worden om een zo zuiver mogelijk beeld te krijgen van de waarde van het kapitaal op de balans.

- Bufferkapitaal: Volgens risicomodellen moet een bufferkapitaal worden aangehouden, waarbij onder wisselende scenario's de kans op faillissement van de verzekeraar beperkt blijft tot een half procent.

Economic capital is de intern afgeleide maatstaf voor bufferkapitaal. Doff (2006) definieert economic capital als de benodigde minimale vermogensbuffer voor het opvangen van onverwachte verliezen en waardedalingen uit hoofde van de diverse risicocategorieën in een gekozen tijdsperiode (vaak één jaar) en met een gegeven betrouwbaarheidsinterval. Het betrouwbaarheidsinterval is gebaseerd op de interne ratingdoelstelling van de verzekeringsmaatschappij. Het voordeel van economic capital is dat het bij uitstek geschikt is voor het creëren van risicogecorrigeerde prestatiemaatstaven. Risico's worden onderling vergelijkbaar door hun gewicht in economic capital die ze vereisen. Rendement op verzekeringsproducten kan worden gecorrigeerd voor hun risicoprofiel door de kapitaalkosten voor het economic capital mee te nemen om te komen tot economic profit. 
De invoering van Solvency II heeft een extra stimulans gekregen door de kredietcrisis. De maatschappelijke noodzaak van een krachtige solvabiliteit van verzekeraars en een toereikend instrumentarium voor de toezichthouder om daarop toe te zien is duidelijk geworden. De verzekeraars zelfzien meer als ooit de meerwaarde van voldoende bufferkapitaal. Vanuit een veranderkundige blik is de invoering van Solvency II en daarmee een versterkt Enterprise Risk Management (ERM) model een stuk gemakkelijker geworden. De noodzaak is bij iedereen in de organisatie duidelijk, waardoor de weerstand tegen bijvoorbeeld het verankeren van risicogecorrigeerde maatstaven in de prestatiemeting en prestatiebeloning een stuk lager zal zijn.

\section{Rol van verzekeraars in het financiële systeem}

Om meer inzicht te krijgen in waarom interne beheersing zo belangrijk is voor verzekeraars wordt in deze paragraaf eerst beschreven wat verzekeraars zijn en doen en welke risico's zij lopen met hun bedrijfsactiviteiten.

De kerntaak van het verzekeringsbedrijf is het bieden van financiële zekerheid aan consumenten en ondernemingen in een risicovolle maatschappij. Het verzekeringsbedrijf is in principe gebaseerd op een inversie van de exploitatiecyclus. Dit wil zeggen dat de dienstverlening aan de verzekerde pas geschiedt nadat de verzekerde daarvoor heeft betaald (Van Ewijk en Scholtens, 2003). Verzekerden betalen periodieke of eenmalige premies waar tegenover een verplichting van de verzekeraar staat voor te verrichten uitkeringen bij overlijden of bij leven. Tot die tijd dienen de voor de uitkeringsverplichtingen benodigde gelden te worden belegd. Bij levensverzekeraars vindt vermogensvorming plaats door toepassing van het kapitaaldekkingsstelsel. De premies worden gebruikt voor de vorming van een fonds, waaruit uitgekeerd wordt bij overlijden of bij het bereiken van een bepaalde leeftijd. Levensverzekeraars moeten premies en koopsommen zo beleggen, dat de aangegane verplichtingen uit de middelen kunnen worden voldaan (Krishan, 2007).

Bij schadeverzekeringen worden eenmalige of periodiek vervallende premies betaald waarbij de verzekeraar verplichtingen aangaat bestaande uit schadevergoedingen voor schade voortvloeiende uit onzekere gevallen. Het is daarom onzeker of op een polis een uitkering zal worden gedaan, of dat er meerdere schaden vallen en daarmee ook meerdere schadevergoedingen zullen worden gedaan. De periode die verstrijkt tussen de premieontvangst en de eventuele uitkering is betrekkelijk kort. Vanwege het onzekere verloop van het schadepatroon moet de schadeverzekeringsmaatschappij een fors buffervermogen aanhouden en moeten de beleggingen snel en tegen geringe kosten te liquideren zijn. De vorderingen van de schadeverzekeraar zijn daarom in het algemeen goed verhandelbare effecten, vooral obligaties en aandelen.

Bij schadeverzekeraars ligt het zwaartepunt op de verzekeringstechnische risico's. Levensverzekeraars lopen daarnaast ook marktrisico's op de beleggingsportefeuille. Hoewel bij verzekeraars ook andere risico's relevant kunnen zijn, geldt dat de zojuist genoemde risico's veruit dominant zijn. Verzekeraars hebben dan ook bijna geen liquiditeitsrisico. Solvabiliteit (zijn er voldoende buffers om op lange termijn aan de verplichtingen te voldoen) is voor hen veel belangrijker en wordt vooral beïnvloed door de behaalde rendementen op het vermogensbeheer. Een van de grootste onderliggende risico's is dan ook dat de behaalde rendementen structureel lager zijn dan de afgegeven rendementsgaranties. Met hun activiteiten nemen verzekeraars bewust risico's. Het voortbestaan van de activiteiten van een verzekeraar en het maken van winst (voor een commerciële verzekeraar) kan ook alleen als zij deze risico's blijft nemen. Aan de andere kant vertrouwen de cliënten van verzekeraars hun middelen toe aan verzekeraars in de verwachting dat zij deze zorgvuldig beheren en de overeengekomen verplichtingen ook daadwerkelijk nakomen. Verzekeraars zullen dit vertrouwen moeten waarborgen. Een verzekeraar zal een goede balans moeten vinden in het nemen van risico's welke onlosmakelijk gepaard gaan met hun kerntaak en het beheersen en minimaliseren van deze risico's om het vertrouwen van cliënten en andere belanghebbenden in de organisatie te waarborgen (Krishan, 2007). Dit is niet alleen belangrijk voor het voortbestaan van een verzekeraar, maar voor de algehele economie gezien de rol die de verzekeraar vervult in het economische systeem.

\section{Het begrip interne beheersing}

Ten aanzien van interne beheersing zijn de laatste jaren veel publicaties verschenen. In het artikel Interne beheersing: in control of in de krant van Emanuels (2005) is het begrip interne beheersing als volgt gedefinieerd:

'Het systeem dat het management in staat stelt om de risico's, die het behalen van doelstellingen van de organisatie bedreigen, te identificeren, te prioriteren, te analyseren en te beheersen.' (Emanuels, 2005).

Uit deze definitie kan worden geconcludeerd dat interne beheersing betrekking heeft op het beheersen van risico's ten aanzien van het realiseren van de ondernemingsdoelstellingen. Interne beheersing dient daarmee als hulpmiddel bij het waarborgen dat de doelstellingen van de onderneming ook op langere termijn worden bereikt. Een bijkomstigheid is dat met interne beheersing ook kan worden gewaarborgd dat een onderneming handelt binnen de wettelijke en ethische normen. $\mathrm{Na}$ de beursschandalen 
zijn diverse wetten en regels opgesteld om ervoor te zorgen dat ondernemingen acceptabele risico's nemen. Deze weten regelgeving dienen ondernemingen mee te nemen in het beoordelen en beheersen van hun risico's. Verder kan interne beheersing een bijdrage leveren aan de betrouwbaarheid van de financiële verslaggeving.

De kanttekening die moet worden gemaakt is dat zelfs de meest effectieve interne beheersing niet meer kan doen dan een redelijke mate van zekerheid verschaffen in de realisatie van de ondernemingsdoelstellingen. Met interne beheersing kan informatie worden gegenereerd over de mate waarin verwacht wordt dat de onderneming haar doelstellingen kan realiseren. Maar veranderingen in overheidsbeleid, initiatieven van de concurrentie of economische omstandigheden liggen buiten de invloedssfeer van het interne beheersingsysteem van een onderneming. Daarnaast kunnen interne beheersingsmaatregelen worden omzeild als meerdere personen binnen de onderneming bewust kwaad willen en ook het management heeft altijd de mogelijkheid om de interne beheersing te doorbreken.

Internationaal wordt interne beheersing doorgaans ingevuld op de manier zoals dat in het COSO Framework is beschreven. COSO geeft met haar model een referentiekader voor interne controle om het management te ondersteunen bij de verbetering van het interne controlesysteem. De kracht van het COSO-model voor interne beheersing is dat het goed aansluit bij het proces dat het management doorloopt bij het inrichten van controls.

Een ander model gericht op interne beheersing is die van Simons (1995). De 'levers of control' van Simons bieden houvast voor de 'volledigheid' ten aanzien van de vier dimensies van management control - en indirect voor de soorten van controls (Ellenbroek, 2005). Simons' theorie is vanuit het perspectief van het management geschreven. Simons stelt dat management control de resultante is van vier typen 'control systems'. Simons onderkent de 'belief systems', 'boundary systems', 'interactive control systems', en de 'diagnostic control systems'. Deze vier systemen dienen continu in balans te zijn.

De beliefsystems hebben betrekking op het uitdragen van de visie, missie en gedragscode van de organisatie, alsmede het motiveren van personeel.

De boundary systems hebben betrekking op het stellen van limieten, te denken valt aan het positioneren van de organisatie, het definiëren van de product-/marktcombinaties, het vaststellen van een acceptabel risiconiveau, het vaststellen van bevoegdheden en het bepalen van niet-wenselijk gedrag.
Figuur 1 De 'levers of control' van Simons (1995)

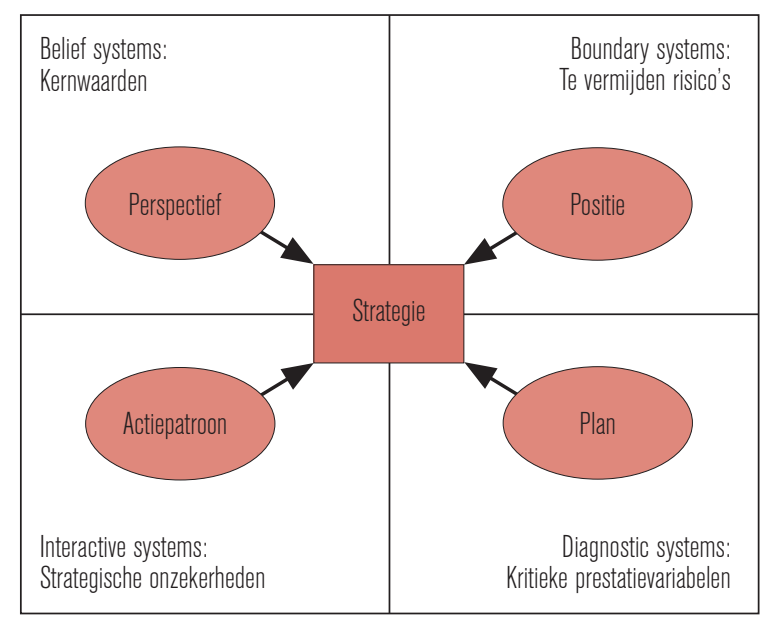

De interactive control systems richten zich op het lerend vermogen van de organisatie en het zoeken naar kansen, het waarnemen van veranderingen in de markt en het bediscussiëren van data, veronderstellingen en plannen. De diagnostic control systems richten zich op het behalen van doelen. Hierbij vindt een vergelijking plaats tussen het gestelde doel en het behaalde resultaat en worden verschillen verklaard.

Doordat COSO eenvoudig valt te operationaliseren is het een krachtig model. Het model van Simons is echter sterk omdat het beter de keuze van het type control systems ondersteunt. Dit vraagstuk op strategisch en tactisch niveau - wat bestuur je waarmee - is juist hier interessant. Vanuit het onzekere uitgangspunt van de kredietcrisis wensen we hier met een open blik te kijken naar de keuzes die verzekeraars moeten maken in hun portfolio van control systems. Daarom hebben wij ervoor gekozen om in dit artikel het model van Simons te gebruiken voor het toetsen van de 'volledigheid' van interne beheersing bij AIG en het geven van aanbevelingen voor het verder optimaliseren van de interne beheersing bij verzekeraars. De 'volledigheid' van de interne beheersing zien wij daarmee als een graadmeter voor de effectiviteit. Het zorgt ervoor dat de verzekeraars hun strategische doelen beter kunnen realiseren zelfs in zeer turbulente tijden als een kredietcrisis.

\section{Een analyse van de interne beheersing bij AIG}

\section{Introductie AlG-casus}

De kracht van casestudies ligt in de mogelijkheid om te leren van ervaringen die eerder zijn opgedaan. Vaak zijn deze casestudies succesverhalen om te leren wat je moet doen om succesvol te zijn. In het kader van dit artikel over de interne beheersing van verzekeraars in het licht van de 
kredietcrisis hebben we voor een ander type casestudie gekozen waar we heel veel van kunnen leren, namelijk: AIG. De AIG-casus wordt geanalyseerd aan de hand van het interne beheersingsmodel van Simons, zoals het in de voorgaande paragraaf is besproken. Wij baseren ons daarbij op openbare bronnen. Vooral het artikel van Gretchen Morgensson in The New York Times: Behind Insurer's Crisis, Blind Eye to a Web of Risk staat hierin centraal (Morgensen, 2008).

's Werelds grootste verzekeraar AIG is het meest in het oog springende voorbeeld van een verzekeraar die in de kredietcrisis door de US overheid gered moest worden. Het Amerikaanse bedrijf was in 1919 door de zoon van Nederlandse immigranten opgericht en is intussen uitgegroeid tot een bedrijf dat in 2007 een omzet rapporteerde boven de 100 miljard US dollar met een waarde van zijn activa boven de 1000 miljard dollar.

De New York Times spreekt van een virus dat explodeerde vanuit een "freewheeling" klein bedrijfsonderdeel in Londen. Het bedrijfsonderdeel is AIG Financial Products (AIG-FP) en had 377 personen voor zich werken ( $0,3 \%$ van het personeelsbestand van AIG). Het bedrijfsonderdeel wordt gekenschetst als een bijna autonoom onderdeel dat met ijzeren hand werd bestuurd door de lokale directeur.

AIG-FP was een aantal jaren geleden ingestapt in de verzekering van portefeuilles van leningen van banken. De banken werden door AIG-FP verzekerd voor het kredietrisico dat ze lopen op deze leningen, waardoor deze banken minder door de wetgever vereist bufferkapitaal aan hoefden te houden. Deze verzekering vond plaats door middel van complexe derivaten: Credit Default Swaps (CDS's) op Collaterized Debt Obligations (CDO's). Het zijn juist deze complexe financiële producten die de reden zijn dat de Amerikaanse huizencrisis is geëxplodeerd tot een wereldwijde kredietcrisis. Door de huizencrisis werd er meer en meer aanspraak door banken gedaan op AIG-FP om voor het onderpand te zorgen zoals overeengekomen in de CDStransactie. AIG-FP moest vervolgens bij het moederbedrijf AIG aankloppen omdat ze deze verplichtingen niet meer kon nakomen. In het volgende geven wij een analyse van de AIG-casus en de interne beheersing op basis van de vier control systems van Simons (Simons, 1995).

\section{Belief systems}

Voor belief systems is vooral op te merken dat er binnen AIG-FP sprake was van directief leiderschap. Dit leidt er toe dat missie en visie niet breed uitgedragen wordt. De kennis binnen de organisatie was verder sterk persoonsgebonden en niet ontwikkeld bij anderen zodat er een grote afhankelijkheid was van één persoon. Dit bleek uit het feit dat de heer Cassano, die als directeur van AIG-FP is ontslagen na een verlies van \$ 11 miljard, vervolgens weer werd ingehuurd als consultant voor \$1 miljoen per maand. AIG wilde hiermee de kennis van de transacties behouden (Ahrens, 2008).

\section{Boundary systems}

Met boundary systems moeten ongewenste risico's in organisaties worden voorkomen door het beperken van vrijheden en controle hierop uit te voeren. Binnen een verzekeringsconcern moet duidelijkheid zijn over welke verzekeringsproducten, beleggingsproducten en derivaten in welke mate zijn toegestaan en welke juist niet zijn toegestaan. Bij AIG waar het risicomanagement voldoende was ingericht om wereldwijd verzekeringsvergunningen te bezitten, ging het toch mis. Het is de vraag of het topmanagement van AIG het risicoprofiel van de derivaten voldoende helder had en in hoeverre zij een stem hebben gehad in de keuze om in de CDS's te stappen.

AIG-FP had een grote mate van onafhankelijkheid gekregen van de moedermaatschappij. Het topmanagement van het moederbedrijf AIG werd gesteund in deze beslissing door de zeer goede resultaten die de dochter tot voor kort had geboekt. De kleine unit leverde in 2005 meer dan 17\% van de operating income. Een natuurlijke beweging in management control is dat organisaties die goed draaien meer met rust worden gelaten door het hoger management en daardoor meer autonomie krijgen. Maar als duidelijk was geweest hoeveel risico's er schuil gingen achter de grote winsten (met operationele winstpercentages van $80 \%$ ) dan had het moederbedrijf hier meer controle op uit willen voeren.

\section{Interactive control systems}

Het directief leiderschap heeft ook zijn impact op de interactive control systems. Managementdiscussies over strategische onzekerheden vinden dan onvoldoende plaats. Onbekend is in hoeverre het management van AIG-FP zijn beleid tegen scenario's heeft aangehouden waarin extremen zijn doorgerekend van onzekerheden zoals prijspeil van het onderpand en het aantal faillissementen. Hadden ze deze twee belangrijke onzekerheden geanalyseerd tegen een 'worst-case'-scenario dan hadden ze zeker een andere keuze van producten gemaakt, dan wel voor de juiste voorzorgsmaatregelen gezorgd.

\section{Diagnostic control systems}

$\mathrm{Na}$ het toewijzen van de beslissingsrechten is het volgens Brickley (2001) van groot belang om prestatiemeting en beloning hiermee in balans te brengen. Deze laatste twee onderdelen van dit 'management control krukje' spelen in de AIG-casus een belangrijk samenspel in de diagnostic control systems. De beloning is namelijk sterk gerelateerd aan de gemeten prestaties.

\section{Prestatiemeting}

Risico en rendement moeten sterk verankerd zijn in de 
prestatie-indicatoren waarop gestuurd, beoordeeld en beloond wordt in een verzekeringsbedrijf (Hillenga, 2008). Puur sturen op winst past niet bij de karakteristiek van een verzekeringsbedrijf. Hierin is namelijk het risicoprofiel onvoldoende verwerkt.

De complexiteit van de producten maakten de juiste meting van de prestatie bij AIG-FP lastig. Uiteraard was de operating income wel vast te stellen, maar tegen welk risico was lastiger te meten. In de weging van de prestatie moet echter altijd het risicoprofiel worden meegenomen om te voorkomen dat juist de risicovolle producten worden opgezocht. AIG-FP had daarbij een slecht track record in de waardering van zijn producten. Ten eerste had het in $2004 \$ 126$ miljoen betaald om te schikken in een zaak, waarin het werd verdacht klanten te helpen met het oppoetsen van hun balans. Later kreeg AIG-FP problemen over de waardering van haar derivaten en vervolgens werden in februari 2008 door de externe accountant onregelmatigheden aangetroffen in de externe verslaggeving van derivaten.

Door de opzet als bankbedrijf in plaats van verzekeringsbedrijf stond AIG-FP niet onder toezicht van verzekeringstoezichthouders en hoefde het geen bufferkapitaal aan te houden voor de risico's die het liep met de derivaatcontracten die het afsloot. De vertaling van risico's naar kapitaalsbeslag heeft mede daardoor onvoldoende plaatsgevonden.

\section{Prestatiegerelateerde beloning}

De beloningsstructuur bij AIG-FP was extreem gerelateerd aan de prestatie. Volgens de Washington Post (Ahrens, 2008) ging van iedere dollar die werd verdiend 30 cent naar het management van AIG-FP. In de laatste zeven jaar betaalde AIG-FP haar werknemers (slechts 377 personen) meer dan \$3,5 miljard.

De beloningstructuur was daarbij niet gecorrigeerd voor het risico dat werd gelopen. Doordat er geen bufferkapitaal aangehouden hoefde te worden voor de risico's die het liep was een goede rendementrisicobeoordeling afwezig. Er ontbrak een prestatiebeloning die rekening hield met de duurzaamheid van de winstgevendheid.

\section{Aanbevelingen voor een effectieve interne beheersing van een verzekeraar}

De verzekeringssector bevindt zich in een turbulente periode. Zowel de kredietcrisis als de toename van wet- en regelgeving hebben het vraagstuk van interne beheersing op de agenda van vele ondernemingsbesturen gezet, maar dat alleen zal naar verwachting niet leiden tot het beoogde effect. Op basis van de analyse van de interne beheersing bij AIG en de ambities die verzekeraars hebben, zien wij een aantal ontwikkelpunten voor verzekeraars. Deze ontwikkelpunten hebben wij vertaald naar zes aanbevelingen voor een meer effectieve interne beheersing van een verzekeraar.

\section{Leiderschap}

Sterk en integer leiderschap is nodig om de juiste toon aan te slaan en de veranderingen door te voeren die nodig zijn om tot effectieve interne beheersing bij verzekeraars te komen. Door de gehele organisatie moeten verzekeraars in de genen - core values - hebben dat rendement gepaard gaat met risico. In alle elementen van de 'belief systems', zoals communicatie (onder andere de 'tone at the top'), opleiding, werving, selectie en leiderschapsstijl, moet hier aandacht aan worden besteed. Daarmee wordt een risicoomgeving gecreëerd waarin, voor zowel externe als interne stakeholders, helder is welk risiconiveau wordt nagestreefd (vergelijkbaar aan de 'risk-appetite' uit het COSO-model).

\section{De inrichting van de organisatie}

Bij AIG zagen we dat risicomanagement in opzet wel goed was ingericht, maar in de werking niet het effect had als dat het zou kunnen hebben. Risicomanagement werd te formeel benaderd. Naast de formele bekrachtiging van risicomanagement zal risicomanagement namelijk ook verankerd moeten zijn in het interne beheersingssysteem en daarmee in alle delen van de organisatie. Het verdient de voorkeur om hierbij in de governance uit te gaan van de Three Lines of Defence waarbij bij elke 'verdedigingslinie' een koppeling wordt gemaakt tussen risico en rendement. De Three Lines of Defence bestaan uit de Business (eerste line of defence), de Risicomanagement-functie (tweede line of defence) en de auditfunctie (derde line of defence). De meeste verzekeraars maken al gebruik van de Three lines of Defence voor de inrichting van hun interne beheersingssysteem. Hierbij nog een aantal punten waar verzekeraars op moeten letten.

Vanuit de Business begint interne beheersing bij een topmanagement die internalisering van een risicobeheersingcultuur, gedreven vanuit een heldere toonstelling aan de top, nastreeft. Hierbij dient voortdurend aandacht te zijn voor de risicorendementafweging in strategische keuzes, prestatiemeting en -beoordeling. Dit kan verder worden versterkt door aan te moedigen dat risico's worden besproken bij keuzes op ieder niveau in de organisatie. Een belangrijk hulpmiddel hierbij is het centraal dicteren van risicogecorrigeerde prestatiemaatstaven voor het beoordelen van business cases, begrotingen en realisaties. Bufferkapitaal ofwel economic capital moet hierin een centrale rol spelen.

De Risicomanagementfunctie moet vanuit een sterk gecentraliseerd orgaan controle uitvoeren op de risico's binnen de verzekeringsmaatschappij. Het zorgt voor een continue monitorfunctie op externe en interne ontwikkelingen die impact kunnen hebben op het risicoprofiel van de organisatie en toezicht op de realisatie van bijstellingen naar 
aanleiding van gesignaleerde tekortkomingen en gebreken. Nieuwe producten en constructies moeten daarbij worden getoetst aan een vaste set van criteria en uitgangspunten waarin risico en rendement worden afgewogen. Trap hierbij niet - zoals bij AIG - in de valkuil dat deze gecentraliseerde controles minder nodig zijn voor de goed presterende onderdelen.

De Risicomanagementfunctie zorgt daarbij voor een consistente uitrol van een centraal gedefinieerd economic capital risicomodel in de organisatie. Hiermee stelt het de business in staat om de eerste line of defence goed in te vullen. De auditfunctie moet de opzet en werking toetsen van de risicobeheersingsmaatregelen die in de eerste en tweede line of defence nodig zijn voor een goede interne beheersing. Hierbij moet een onafhankelijk oordeel worden gegeven over het ontwerp en de effectiviteit van de interne beheersingsmaatregelen inzake risico's die van invloed zijn op de ondernemingsdoelstellingen.

\section{Een sterke kapitaalpositie}

Zoals eerder genoemd zou economic capital een centrale rol moeten spelen in het risicomanagement van een verzekeraar. De crisis heeft aangetoond dat het van groot belang is dat zowel moedermaatschappijen als juridische dochters zelfstandig voldoende kapitaal aanhouden. Met economic capital kunnen risico's onder één noemer worden gebracht, waardoor het rendement gecorrigeerd kan worden met de kapitaalskosten voor het benodigde economic capital. In dit kader en in de eerste line of defence (de Business) speelt het actuariaat een centrale rol. Zij moet zekerstellen dat economic capital en de economic profit maatstaven op een juiste manier worden gehanteerd en dat de kennis en het begrip van deze maatstaven hoog is bij de uiteindelijke gebruikers. Vaak wordt er door actuarissen gebruik gemaakt van risicomodellen. Actuarissen moeten voldoende aandacht besteden aan het delen en inzichtelijk maken van de door hen gebruikte modellen en methoden. Bij belangrijke beslissingen wordt voor de risico-inschatting vaak gebruikgemaakt van de uitkomsten van actuariële modellen en risicomodellen. Het is de verantwoordelijkheid van het management om deze risicomodellen te doorgronden en voldoende begrip te hebben van de werking ervan om een verantwoorde beslissing te kunnen nemen. Actuarissen moeten hiervoor in de organisatieopzet dichter op de business worden geplaatst. Het management zou het risico en bijbehorende rendementen uit deze risicomodellen moeten begrijpen en zich verre moeten houden van producten en investeringen waarvan het het risico niet volledig begrijpt. Verder moeten risicolimieten op basis van economic capital scherp omgeven zijn met geautomatiseerde en business controls in de operationele verzekerings- en assetmanagementprocessen.

\section{Het beheersen van strategische onzekerheden}

Een beproefd middel om strategische onzekerheden te lijf te gaan is scenarioplanning. De strategische discussie wordt bij scenarioplanning ondersteund door het ontwikkelen van een beperkt aantal toekomstscenario's van de buitenwereld waarin een organisatie opereert. Rietdijk en Van Winden bieden een scenariomodel gebaseerd op de 'diepvriesvraag': Stel dat je vier jaren ingevroren bent geweest, wat zou je dan als eerste willen weten? (Rietdijk en van Winden, 2003). De twee belangrijkste externe onzekerheden voor het management worden uit de antwoorden hierop afgeleid. Door van beide onzekerheden een extreem positief en een extreem negatief toekomstperspectief te kiezen, worden vier toekomstscenario's ontwikkeld, waartegen de robuustheid van gekozen beleid getoetst kan worden.

Ook verzekeraars zouden gebruik kunnen maken van scenarioplanning om hun strategische onzekerheden in kaart te brengen. Hierbij zou aandacht moeten zijn voor risico's die niet in het risicomodel zitten. Dit kan door bijvoorbeeld gebruik te maken van scenarioanalyses die ook factoren gebruiken die niet in het risicomodel zitten. Daarnaast kan het zoeken naar antwoorden voor de strategische onzekerheden bewerkstelligd worden door frequent kennis en inzicht te delen. Communicatie zou hierbij als belangrijk instrument voor sturing, terugkoppeling en samenwerking moeten zijn ingebed in de bedrijfscultuur. Alle managementlagen binnen de organisatie dienen betrokken te worden bij discussies over strategische onzekerheden en iedereen in een leidinggevende positie zou moeten begrijpen hoe het interne beheersingssysteem zijn afdeling en zijn processen raakt.

\section{Beloningsstructuren}

De beloningsstructuren worden vaak genoemd in de discussies rondom het ontstaan van de kredietcrisis. De huidige focus op korte termijnbeloning en de daardoor korte termijnfocus op resultaten is aan kritiek onderhevig. Vanuit de agencytheorie is gebleken dat beloningen een krachtig middel zijn om het gedrag van mensen te beïnvloeden. Toch is de koppeling tussen beloning en prestatieindicatoren sterk voor verbetering vatbaar. Bij het belonen van het lijnmanagement dient bijvoorbeeld substantieel rekening te worden gehouden met de kwaliteit van de interne beheersing en niet alleen met de financiële performance op korte termijn. Interne beheersing zou hierbij onderdeel moeten worden gemaakt van de resultaten waarop het management en de business worden afgerekend. De beloningen van functionarissen die in de Risicomanagementfuncties opereren behoren niet resultaatafhankelijk te zijn en er moet worden gewaarborgd dat deze functionarissen problemen met betrekking tot interne 
beheersing (kunnen) melden, aan bijvoorbeeld het audit committee of aan de externe accountant. Daarnaast zou moeten worden nagedacht over wie er toezicht houdt op de berekening en toepassing van de beloningsinstrumenten. In dit kader zou een onderneming moeten kunnen verantwoorden op welke wijze het risico van disfunctioneel gedrag bij hoge beloningen wordt tegengegaan. Daarnaast kan nog worden opgemerkt dat prestatiebeloning slechts één manier is om mensen te prikkelen; promoties blijken nog veel sterker te werken (Cools, 2005). Een verzekeraar zou ook kunnen nadenken over een groter gebruik van dergelijke instrumenten om het gedrag van haar mensen te beïnvloeden.

\section{De rol van consument en verzekeraar}

De afgelopen jaren heeft de nadruk bij de relatie tussen de consument en verzekeraar gelegen op de bescherming van de consument tegen misleidend gedrag van de verzekeraar. Hiertoe zijn wetten en regelingen geïnitieerd. Omdat financiële producten complex kunnen zijn voor een consument is het belangrijk dat deze voldoende transparant zijn voor een consument om hierover een geïnformeerde beslissing te kunnen nemen. Hierin beschermt onze maatschappij terecht consumenten tegen misleidend gedrag van bedrijven. Wat hierbij over het hoofd lijkt te worden gezien is dat iedere beslissing in het leven een mate van risico met zich meebrengt en dat de persoon die een geïnformeerde beslissing neemt, ook (een deel van) dit risico zou moeten dragen (Blom en Keunen, 2009). Het is voor zowel de verzekeraar als de consument van belang dat de consumenten producten kiezen die bij hen passen. Of een product ook bij de consument past is een gedeelde verantwoordelijkheid tussen hem en de verzekeraar. Hoe complex een verzekeringsproduct kan zijn, de consument ontkomt er niet aan zich te verdiepen in het product dat hij wil aanschaffen en zal ook zelf verder moeten kijken dan het advies van de verzekeraar. Van een consument mag worden verwacht dat deze ook zelf verantwoordelijk is voor het krijgen van een goed beeld over het product en welk risico daarbij wordt gelopen (Schilder, 2007). Aan de andere kant zal de verzekeraar ook een goed beeld moeten krijgen van wat de consument met het product wil bereiken en welk product het beste bij hem past. Dit samen zal moeten leiden tot een besef bij de consument over het doel dat hem voor ogen staat, en welk risico dat voor hem betekent. Op basis hiervan kan de consument een geïnformeerde beslissing nemen over het risico zelf dragen of overdragen aan een verzekeraar.

\section{Conclusie}

De kredietcrisis heeft duidelijk impact op verzekeraars. De verzekeraars worden onder andere door de consument en de toezichthouder gedwongen meer terug te keren naar hun traditionele kerntaak van risico dragen en verspreiden, in plaats van het handelen in risico's.

Sterk en integer leiderschap is nodig om de strategie en interne beheersing van verzekeraars hierop aan te passen. Scenarioplanning biedt hierbij goede mogelijkheden om beter in staat te zijn strategische onzekerheden aan te kunnen. Risicogecorrigeerde prestatiemeting en daaraan gekoppelde beloning, gebaseerd op een sterk gecontroleerd economic capital model, maken het mogelijk om in de gehele organisatie risicorendement afwegingen in te bedden in de besluitvormingsprocessen. Dit, in combinatie met een verbeterde interne beheersing in de drie lines of defence - business, risicomanagement en audit -, zou ervoor moeten zorgen dat verzekeraars in de toekomst beter bestand zijn tegen negatieve verrassingen zoals de kredietcrisis.

De auteurs zijn allen werkzaam voor het onderdeel Financial Leadership in Financial Services van Atos Consulting. Drs. F. Smeulders RA is partner; Ir. J.A.H. Hillenga RC is executive business consultant en Drs. S. Krishan is business consultant. 


\section{Literatuur}

- Ahrens, F. (2008) Joe Cassano: The man who brought down AIG?, Washington Post.

Battles, P. en E. Groot (2008), Wellink: crisis nog lang niet voorbij, Het Financiële Dagblad, 4 april 2008, p.5.

- Blom, F. en J.W. Keunen (2009), Bouwen aan een meer crisisbestendige verzekeringssector in Nederland. Lessen uit de kredietcrisis, Boston Consulting Groep; zie: http://www.verzekeraars. nl/UserFiles/File/download/BCG\%20 rapport\%20-\%20Bouwen\%20aan\%20 een $\% 20$ meer $\% 20$ crisisbestendige $\% 20$ verzekeringssector.pdf.

Brickley, J.A., C.W. Smith Jr. en J.L. Zimmerman (2001), Managerial economics and organizational architecture. Boston: McGraw-Hill Irwin. - Committee on Sponsoring Organizations of the National Commission on Fraudulent Financial Reporting (Treadway Committee), Internal Control:
Integrated Framework; zie: www.coso.org. - Cools, K. (2005), Controle is goed, vertrouwen nog beter: Over bestuurders encorporate governance, study for Stichting Management Studies (SMS), Assen: Koninklijke Van Gorcum BV.

Doff, R. (2006), Risicomanagement bij verzekeraars, Risicobeheersing, Economic Capital, Toezicht en Solvency II, NIBE-SVV. EEllenbroek, A.B.T. (2005): 'Veiligheid in control', Universiteit van Amsterdam.

- Emanuels, J.A. (2005), Interne beheersing: In control of in de krant? Rijksuniversiteit Groningen.

Ewijk, C. van, en B. Scholtens (2003), Geld, financiële markten en financiële instellingen,.

Stenfert Kroese

- Hillenga, J.A.H. (2008), Market consistent performance management under Solvency II,
Thesis Executive Master in Finance and Control Nyenrode.

- Krishan, S. (2007): Het ontwikkelingsstadium van compliance management binnen banken en verzekeraars in Nederland, Vrije Universiteit.

Morgenson, G., (2008), The reckoning, behind insurer's crisis, blind eye to a web of risk, The New York Times, 28 September 2008.

- Rietdijk, M. en M. van Winden (2003), Slag om de toekomst, bedrijfsstrategieën voor goeden en slechte tijden, Balans.

- Schilder, A. (2007), Complexe financiële producten, DNB Symposium Complexe financiële producten, Amsterdam.

- Simons, R. (1995), Levers of control, How managers use innovative control systems to drive strategic renewal, Boston: Harvard Business School Press.

\section{Noten}

1 Het Financieele Dagblad 22 januari 2008, p.1.

2 www.verzekeraars.nl 